\title{
Teachers' Discriminations in the Narratives of Primary School Students of Different Periods in Turkey: 1950s, 1970s and 1980s
}

\author{
Mehmet Saglam ${ }^{1, *}$, Hilmi Sungu ${ }^{2}$ \\ ${ }^{1}$ Department of Pre-school Education, Faculty of Education, Bozok University, Turkey \\ ${ }^{2}$ Department Educational Sciences, Faculty of Education, Bozok University, Turkey
}

Copyright $\mathrm{C} 2015$ by authors, all rights reserved. Authors agree that this article remains permanently open access under the terms of the Creative Commons Attribution License 4.0 International License

\begin{abstract}
This study zeros in on rendering the teachers' discriminations among their students in various aspects in the narratives of primary school students of 1950s, 1970s and 1980s' Turkey. Construction and reconstruction of personal and social stories of teachers and students is also a sort of education and educational research. The method of the research is oral history through the agency of which it was possible to disclose the narratives of primary school students about their teachers' discriminations that basically appear as male-female, poor-rich and hardworking-lazy. In doing so, twenty students from 1950s, fifty students from 1970s and thirty students from 1980s' Turkey have been reached and interviewed at different times since 2010. Apart from these hundred students, ten more interviews were carried out for testing. About thirty of the interviewees assert that their teachers had segregated them because of being rich or poor, hardworking or lazy and gender. There are also about ten other students who state that their teachers had discriminated them due to being children of civil servant, neighbor relations, children of working mothers, speaking Turkish properly and parents' political views. The narratives in the research denote that teachers' discriminations had kept going in the course of time despite the progress in the social, economic, political and educational conditions of country. While their narratives are originally presented in the text, the real names of the narrators are not used, instead they are renamed. These narratives are crucial to see the teachers' educational practices in the words of their students who reveal on what basics their teachers discriminated them or not. The study exposes that despite the fact that forty three students remark their teachers discrimination resulted from certain factors, fifty seven students do not recollect any discriminations and believe that their teachers behaved them equally. It displays that discrimination is remarkably faced due to the students' success, their social and economic conditions; gender and income rates. It also proves that the words of most of the students gainsay how their teachers had been fair to their students.
\end{abstract}

Keywords Discrimination, Primary School Students, Turkey, Education, Narratives

\section{Introduction}

Standard historical works rarely captures the voice of ordinary person and thus it is certainly warranted and has presently become a vivid field of research [11]. Narrative is necessary to be used in educational research it is because as Connelly and Clandinin put it 'humans are storytelling organisms who, individually and socially, lead storied lives. Teachers and learners are storytellers and characters in their own and other's stories' [4]. Therefore, educational experiences of students have been pivotal field for the studies on education and history of education that contributes to individual and civic identity [11]. In Depaepe's notable words, 'the importance of the history of education as a discipline is that it has practical, theoretical, educational and intrinsic value. The intrinsic or personal educational values include the cognitive moulding and shaping of a personal and civic identity' [11].

Teachers' educational memories [7] and those of students have been forerunners of scientific studies about education in the last two decades [16]. Students as one of the basic elements of education are to be deemed for both considering questions appearing in education for the past and present in education. Studies on educational research by means of oral education have come in view in various forms. While some of them are directly linked with the educational experiences of individuals as part of educational studies, some are associated with how oral history is utilized in social sciences such as in communication, sociology, history, anthropology, philosophy, psychology, linguistics etc.

Initially, Arslan's Sözlü Tarihin Ortaögretim Öğrencileri Üzerindeki Yansımalarl, Tunceli Merkez Örneği [the 
reflections of oral history on secondary school students, an example of Tunceli city center] aims at uncovering the impacts of oral history information given to the secondary school students by their social milieu. The study reflects that there appears a gap between what is taught at school as part of history lessons and the oral history stories heard from their social environment [2]. In addition to this, Sağlam's 1960-1970 Period Yozgat High School Graduates: Our Teachers goes through the students' memories about their teachers including their teaching methods, disciplines, behaviors. The high school students of the period also recall their teachers due to the discriminations they had been exposed during their high school education [15].

What is more, Roux's [11] Post-graduate Education Students' Oral History Research: a Review of Retired Teachers' Experiences and Perspectives of the Former Bantu Education System focuses specifically on the experiences of teachers that taught under previous education system in South Africa, ie; Bantu Education. The study directed by Tarih Vakfi (History Foundation) in 1998 and called Liseli Gençlerin Gözüyle Cumhuriyetimiz: Yerel Tarih Yarışması (our republic with eyes of high school students, local history competition) includes about fifty local oral history studies of high school students in Turkey. Its objective is to let the students acquire analytic way of thinking and get rid of memorization while considering history courses [8].

As well as the studies performed on education via oral history method there are also studies on the nature of oral history itself and its usage in other social sciences. To begin with, Gardner's [7] Oral history in education: teacher's memory and teacher's history underlines the methodological issues in oral history and the importance of life narratives for the educational researches. In his notable words, he accentuates the necessity of memory as 'exercise of memory as a historical method' [7]. Moreover, Güçlü's study called Eğitim Tarihi Araştırmalarında Sözlü Tarih Uygulaması (the properties and application of oral history method in the research of history of education) tries to produce information about the features and implication of oral history methodology used in history of education by conducting the studies in library, on the internet and related articles [6].

Also Öztürk's Türkiye'de Sözlü Tarihten Illetişim Araştırmalarında Yararlanma Üzerine Notlar (some notes on using oral history in communication studies in Turkey) describes the huge potantials of oral history in order to contribute grasping the progress of oral, written and electronic culture and finds this method as an alternative way of making history. It displays how oral history is made use of in communication studies in Turkey [14]. Sarı's Akademik Tarih ve Tarih Ögrretiminde Sözlü Tarihin Yeri (the importance of oral history in teaching academic history and history) outlines the relation between oral history and academic history, how to use oral history in teaching history by letting them gain certain skills so as to making history learning more enjoyable [18]. Besides, Akbaba \& Kılcan [1] devote a scale to find out prospective attitudes toward oral history in their study named Sözlü Tarih Çalışmalarına Yönelik Tutum Ölçeğinin Geliştirilmesi: Geçerlik ve Güvenirlik Çalışmaları (development of an attitude scale toward oral history: validity and reliability study).

Last of all, despite the fact that there have been studies both on education with oral history methodology and its application in other social fields recently, there are no specific studies on teachers' discrimination of their students with the educational narratives of primary school students of Turkey. With its broad definition discrimination is treatment or consideration of, or making a distinction in favor of or against, a person or thing based on the group, class, or category to which that person or thing is perceived to belong to rather than on individual merit [22]. Discrimination which takes part at schools has appeared for various reasons such as social and economic conditions, gender, race or ethnicity, religious beliefs of individuals. This study reveals a historical perspective about teachers' discrimination of their students in the words of their students.

\section{Methodology}

The data used for this article is based on interviews of primary school students in 1950s, 1970s and 1980s' Turkey that have been conducted since 2010 . Totally 110 including 10 for testing (20 belong to 1950 s, 50 belong to 1970 s and 30 belong to 1980s) students have been reached by snowball method and interviewed by means of oral history $(19,16)$. Oral history research that is the recording in interview form of personal narratives from people with first-hand knowledge of historical or current events allows for the personalization of history and the creation of a counter-hegemonic perspective of history and although subjective, it is no less significant than the narrative of scholars $[11,21]$. Oral history can be used as primary sources or as case studies that connect to core curricula and interdisciplinary subject areas [21].

Le Roux renders the significance of how narrative comes out as an important field for history of education through comparing its entity along with the official documents that basically constitute the history of education. As he puts it in a significant manner 'the official history of education that is best explained as a state or government version of educational provisioning used to justify education policies and practices; a private or detached history of education generated by academics that is influenced by and based on the broad mission and vision statement to which their particular educational institution subscribes; and a collective history of education where the public contribute towards the generation of the content. The latter perspective highlights the contribution that ordinary citizens of a country can make towards the debate on what actually constitutes history. This concept of experience-oriented personalized knowledge generation is grounded firmly in acknowledging the value of how people construe and experience events and the contribution this can make to the creation of a 
counter-hegemonic perspective of history and the shaping of identities' [11].

On this occasion, Kathryn Haynes' telling phrase [9] may contribute this perspective of oral history, 'oral history methodology allows the voices of those that have been partially or totally ignored, marginalized or silenced within particular contexts to be heard'. Narrative as the product of oral history is a way of characterizing the phenomena of human experience and its study which is appropriate to many social science fields. Due to its focus on experience and the qualities of life and education, narrative is situated in the matrix of qualitative research [4]. As a result of this, the educational historians become concerned with the experiences of children and students as well as the problems of teachers and administrators [20]. Namely, it would benefit those of us in the educational community by providing rich data [13].

\section{Study Group}

The universe of the research group is primary school students of 1950s, 1970s and 1980s' Turkey. Forty students of these students were female the rest were male. It was not possible to reach females of 1950 s as they were rarely attending to school.

\section{Research Instrument}

The data gathered for this study were the core of interviews that are conducted between researcher and participant, transcripts are made, the meetings are made available for further discussion, and they become part of the ongoing narrative record [4]. Totally 110 interviews (10 for testing) have been materialized. After the recording, the interviews have been transcribed in their original forms and the text reflecting their diverse memories was reconstituted. The open-ended questions were about their demographic information and the discriminations they had been exposed during their primary school education $[19,16]$.

\section{Procedure}

At the first stage, the primary school students of 1950 s, 1970s and 1980s were reached by snowball method and appointments were organized and they were visited either in their residences or offices. Before the interviews, they filled an oral history data document and then they started to answer some demographic questions and then followed a conversation style with more open-ended questions. After the interviews, an oral history story was written for each interview [19].

\section{Analysis of the Data}

Descriptive analysis was made use of while analyzing the interviews. Hence, what they were able to recall about their teachers' discriminations were put into a context and a relation between their memories and the reasons that led to their recollections were established [3]. The narratives were categorized regarding their contextual similarities [24]. The description of the organized data was directly quoted to the related place in the text in their original form. For the ethical clearance, the validity and reliability of interviews were proved both by getting the approval of the interviewees after decoding the interviews and the help of an academician about the framework provided previously in order to use the narratives in the text $[11,15]$. Also instead of the original names of the interviewers, similar names were used in the text.

\section{Findings}

In this section, primary school students' narratives that picture their teachers' discriminations among their students during their primary school educations at different times in Turkey are presented. Out of hundred, forty three students three of whom narrate more than one type of discriminations indicated that their teachers had segregated them for certain reasons the most remarkable of which are being hardworking or lazy, poor or rich and being male or female. Fifty seven of them emphasized that they had not been subjects of any discriminations.

\section{Hardworking-Lazy}

The narratives which display that teachers did discriminations among their students due to their success are the highest one when compared with the other types of discriminations as it will be seen at table 1 . However, they mostly do not evaluate this discrimination negatively and believe as though it had been their rights. Fourteen narratives in three periods reveal that there appeared teachers' discrimination among the students due to their success. Among the narratives of 1950s 20\% percent claim that their teachers were segregating their students if they had been successful. Undoubtedly, the narratives of Murat Kuralc1, Alpay Recai Kaplan, Mehmet Cerit Yaman and Seyhan Okan demonstrate that the successful students were more favored by the teachers. For example, Mehmet Cerit Yaman puts it as "Those students whose courses better and successful were more favored. Those who were hard-working were mostly chosen for entertaining plays." Seyhan Okan also denotes that "The naughty kids were made to sit at the back desks in the classroom. There were friends of us who were in the same grade for two years. They were a bit discriminated from us."

Among the narratives of 1970s' primary school students, only four of them ( $8 \%$ percent) assert that there was discrimination owing to the students' performance in the classroom. When compared with 1950s, this seems to be quite fair. Ahmet Bozok, Yasin Aksu, Hazal Egeli and Özgür Yildız's reminiscences verify that their teachers discriminated the successful students. To illustrate, Ahmet Bozok's words display this discrimination as "They were definitely discriminating. Namely, they had the successful students sat to frontier desks. Those whose courses were poor were made to sit at the back desks of the classrooms during the third, fourth and fifth grades. As is there had been 
such segregation in the classroom."

When the narratives of those who were primary school students in 1980s are taken into consideration, six students (17\% percent) among thirty students put forward that there was segregation because of the students' achievement or laziness. Gül Ak Karataş, Sonay Yol, Gözde Öksüz, Dilek Öztürk, Şeyda Ayhan and Seyhan Dörtyol words expose that there happened teachers' discriminations on account of the students' successes. For instance, in Gül Ak Karataş's notable words, "I precisely remember this at the fourth and fifth grades. Our teachers liked the successful students more." As Sonay Yol puts it "The teachers were treating a bit more different to the successful students. That is bit different." While she says that's a bit different, she is in the tendency of tolerating that treatment of the teachers. Gözde Özsüz particularly emphasizes this discrimination as "Yes, S/he segregated the successful students. S/he separated the lazy students as they had not studied their lessons." Dilek Öztürk believes that her teachers had a special interest to her as she was a successful student. "Our classroom was very crowded but since I was such a successful student that both my teacher and her husband had had a special interest to $m e$ "

Table 1. Teachers' Discrimination of the Students Due to Their Success

\begin{tabular}{|l|c|c|c|c|c|c|}
\hline Years and the Number & \multicolumn{2}{|c|}{$\begin{array}{c}\text { 1950s (20 } \\
\text { Students) }\end{array}$} & \multicolumn{2}{c|}{$\begin{array}{c}\text { 1970s (50 } \\
\text { Students) }\end{array}$} & \multicolumn{2}{|c|}{$\begin{array}{c}\text { 1980s (30 } \\
\text { Students) }\end{array}$} \\
\hline $\begin{array}{l}\text { Discrimination due to } \\
\text { being hardworking or }\end{array}$ & Yes & No & Yes & No & Yes & No \\
\cline { 2 - 7 } lazy & 4 & 16 & 4 & 46 & 6 & 24 \\
\hline
\end{tabular}

\section{Economic Conditions}

Educational life stories of primary school students of Turkey externalize some examples of discrimination owing to the students' economic conditions that is shown at table 2 . Ten students recount that the economic conditions of the students became decisive in teachers' educational practices while any forms of discrimination observed. The recounts of Deniz Soylu and İlter Öz who were primary school students in 1950s confirm that teachers did discriminate their students because of having better economic conditions. As Deniz Soylu puts it, "While educating, when the students could not answer the questions on the board, he was calling to the board and had me slap in the face of them. I was slapping them. These children more belonged to the poor families." İlter Öz's words picture this discrimination in a profound way. "I think the children of civil servants were privileged as well as those of the rich and notable families. I remember one event that I had experienced. There was a theatre play. I had the chief role. Yavuz Sultan Süleyman and Kanuni Sultan Süleyman, Yavuz was the padisah (monarch), his son was wayward Süleyman. During this play, the photographer had come. We were performing in Military Cinema. He was taking photos of a few people who were performing. The sainted Mr. SSevket said that what I was going to do the photo. I had the chief role. After a forty year period, one of my friends called Isa Çapan showed me those photos. I sorrowed as I was not there."
Four narratives of 1970 s display that the teachers were segregating their students because of being children of rich or poor families. Murat Eren, Selim Yorulmaz, Yeliz Nazlı, Ayşe Zor Duran and İsa Y. Dağlı reflect the discrimination of their teachers with their uncommon words. For instance, Selim Yorulmaz recollects it as "Yes, it was possible to feel this in our classroom. The parents of one child was doing wholesaling and retailing in Kirşehir, those who sell things to the small shopes. Their children were bringing half a kilo of chocolate to the teacher. He was tolerating them. They were not successful but we were thinking that they were privileged. That was our perception at that time." Over and above, İsa Y. Dağlı claims that the income level was effective in teachers' behaviors. "Income level was becoming influential. S/he had better relations with those whose clothes were more proper and belonged to wealthy families. Yet, our teachers were a bit cold to the children who had runny nose and with dirty shoes. They were mostly punished. The punishment they had been exposed was more ruthless while compared with the other guilty students."

Another four recounts that belong to the students of 1980s prove that the teachers did care about economic conditions of the families in their behaviors against their students. Murat Gül, Turan Bölükçe, Gönül Özçelik and Nazlı Nil narrate teachers' discriminations. To illustrate, Gönül Özçelik mentions it as "Yes, s/he was definitely discriminating. S/he especially loved the money. The children who got dressed well and whose parents had bought her presents were more favored. S/he was more sensitive to them. Namely, she loved them. You could notice this as a child." Also Nazlı Nil puts it as "Yes. The children whose economic differences were observed and the children whose parents were more interested in their children and negotiated with their teachers and directors had different relations with the teachers. There was discrimination it was more related with their economic and social status rather than the gender."

Table 2. Teachers' Discrimination of the Students Due to Being Poor or Rich

\begin{tabular}{|l|c|c|c|c|c|c|}
\hline $\begin{array}{l}\text { Years and the } \\
\text { Number } \begin{array}{l}\text { of } \\
\text { Students }\end{array}\end{array}$ & \multicolumn{2}{|c|}{$\begin{array}{c}\text { 1950s (20 } \\
\text { students) }\end{array}$} & \multicolumn{2}{|c|}{$\begin{array}{c}\text { 1970s (50 } \\
\text { students) }\end{array}$} & \multicolumn{2}{|c|}{$\begin{array}{c}\text { 1980s (30 } \\
\text { students) }\end{array}$} \\
\hline $\begin{array}{l}\text { Discrimination } \\
\text { due to being poor } \\
\text { or rich }\end{array}$ & Yes & No & Yes & No & Yes & No \\
\cline { 2 - 7 } & 2 & 18 & 4 & 46 & 4 & 26 \\
\hline
\end{tabular}

\section{Gender}

In general gender in its wide meaning indicates the social roles formed for males and females, learned behaviors, and expectations in a society $[5,10]$. According to another definition, gender means the inequality between masculinity and femininity in social respect. [12]. It is defined by FAO as 'the relations between men and women, both perceptual and material. It is not determined biologically, as a result of sexual characteristics of either women or men, but is constructed socially. It is a central organizing principle of societies, and often governs the processes of production and reproduction, consumption and distribution' [23]. 
Two for each period, six children of these three periods remark that their teachers were discriminating the students on account of their gender that is presented at table 3. It is understood from the narratives that the girls were more tolerated and favored than the boys when particularly the punishment is regarded. For example, Mert Koca and Murat Kuralc1 as primary school students of 1950s explicate that there was a sort of discrimination if it is called as on behalf of girls. Mert Koca puts into words it as "There was, .there were girls in the classroom as well. The teachers had them sit on the frontier desks." Murat Kuralc1 indicates that "There was a little discrimination in favor of girls in terms of beating and discipline."

Nalan Asyalı and Suphi Kahraman being primary school students of 1970s specify that female students were acted more favorably. As Suphi Kahraman recounts, "O course, we could observe that the girls were more privileged when compared with the boys." Nalan Asyal1 puts it as "At that time, periodicals were sent to the teacher. She was always having the same girl distribute them. Since it made me feel sad, I do not do the same to my students now." Furthermore, Ercan Özçelik and Ayşe Zor Duran who were primary school students of 1980s state that the teachers were more careful while acting to the female students. Ercan Özçelik describes it as "My Nursel Çoban teacher was a bit harsher to the boys as they were naughtier." Ayşe zor Duran asserts that "I think s/he was acting girls a bit more rigorously, a bit more protective."

Table 3. Teachers' Discrimination of the Students Due to Gender

\begin{tabular}{|l|c|c|c|c|c|c|}
\hline $\begin{array}{l}\text { Years and the } \\
\text { Number of Students }\end{array}$ & \multicolumn{2}{|c|}{$\begin{array}{c}\text { 1950s (20 } \\
\text { students) }\end{array}$} & \multicolumn{2}{c|}{$\begin{array}{c}\text { 1970s (50 } \\
\text { students) }\end{array}$} & \multicolumn{2}{c|}{$\begin{array}{c}\text { 1980s (30 } \\
\text { students) }\end{array}$} \\
\hline $\begin{array}{l}\text { Discrimination due } \\
\text { to gender }\end{array}$ & Yes & No & Yes & No & Yes & No \\
\cline { 2 - 7 } & 2 & 18 & 2 & 48 & 2 & 28 \\
\hline
\end{tabular}

Discriminations Due to Being Children of Civil Servants, Neighborhood Relations, Children of Working Mothers, Speaking Turkish Properly and Parents' Political Views

Discriminations due to being children of civil servants, neighborhood relations, children of working mothers, speaking Turkish properly and parents' political views are rarely encountered in the students' narratives as they are indicated at table 4. Initially, being children of civil servants, especially those of the teachers may lead to having certain advantages from the point of teachers. One narrative from the students of 1950s, one from the 1970s and three from the 1980s reflect that teachers were discriminating the students as they were children of civil servants such as teachers or bank directors. İlter Öz who was one of the students of 1950s depicts that discrimination as "At that time, children of civil servants were more privileged." The recount of Veysi Kizılmark being a student of 1970s clarifies that "There was discrimination on behalf of teachers and bank directors' children." In addition to these, Musa B1kmaz, Murat Gül and Özmen Ok who got their primary school education in 1980s show forth that the children of teachers and civil servants were favored more. In Murat Gül's telling phrase, "particularly the children of civil servants were promoted." Musa B1kmaz defines that discrimination as "The children of teachers had different positions. For example, if there is a poem competition, their children were chosen."

As well as being of children of civil servants, neighborhood relations appear to be source of discrimination in words of two students of 1970s and 1980s. For instance, Fevziye Erdoğdu getting her primary education in 1970s denotes that there are different factors which were playing role in discriminating students. With her own notable words, "Neighborliness, family relations are important. If you are a child of teacher's neighbor or a child of well-known family, you can be favored."

Additionally, narratives of two students who were at primary school in 1970s and 1980s picture that they were favored by their teachers as either their mothers were working or divorced. Naciye Dertli as one of the 1970s' period primary school student denotes as "At last I felt much that discrimination. There were not many working mothers at that time, as she was a working mother as well she was good to me and a few other children whose mothers were working. "One of the students of 1980s, Şeyda Ayhan whose parents had already been divorced claims that her teachers did care her. "My primary school teacher was always interested in me since my family had told her that my parents had divorced."

Furthermore, Rana E. Ölmez as one of the 1970s' students narrates that a boy who had came from İzmir and got his education in Bingöl was protected as he was not used to cold and could be ill easily because of harsh weather conditions and preferred by the teachers when a duty was in need to be fulfilled by a student. "Since he was so sensitive to the cold whether there, as we were not that much, he was cared by the teacher. Also his Turkish was more proper, the teacher was choosing him when there was a need to send a student somewhere to explain something." As a last account, Aykut Mert Kuş, a primary school student of 1980 s, reveals that there appeared discrimination as a result of political views of families. "As far as I remember, there was an approach because of the parents' political views."

Table 4. Teachers' Discrimination of the Students Due to Various Reasons

\begin{tabular}{|l|c|c|c|c|c|c|}
\hline \multirow{2}{*}{$\begin{array}{c}\text { Years and the Number of } \\
\text { Students }\end{array}$} & \multicolumn{2}{|c|}{$\begin{array}{c}1950 \text { s (20 } \\
\text { students) }\end{array}$} & \multicolumn{2}{c|}{$\begin{array}{c}1970 \text { s (50 } \\
\text { students) }\end{array}$} & \multicolumn{2}{|c|}{$\begin{array}{c}1980 \text { s (30 } \\
\text { students) }\end{array}$} \\
\cline { 2 - 8 } & Yes & No & Yes & No & Yes & No \\
\hline $\begin{array}{l}\text { Discrimination due to } \\
\text { being children of civil } \\
\text { servant }\end{array}$ & 1 & 19 & 1 & 49 & 3 & 27 \\
\hline $\begin{array}{l}\text { Discrimination due to } \\
\text { neighborhood relations }\end{array}$ & - & 20 & 1 & 49 & 1 & 29 \\
\hline $\begin{array}{l}\text { Discrimination due to } \\
\text { being children of working } \\
\text { mothers }\end{array}$ & - & 20 & 1 & 49 & 1 & 29 \\
\hline $\begin{array}{l}\text { Discrimination due to } \\
\text { speaking } \\
\text { properly }\end{array}$ & - & 20 & 1 & 49 & - & 30 \\
\hline $\begin{array}{l}\text { Discrimination due to } \\
\text { parents' political views }\end{array}$ & - & 20 & - & 50 & 1 & 29 \\
\hline
\end{tabular}




\section{Discussion and Conclusions}

As a part of discussion the narratives of the students who were getting their primary school education in 1950s, 1970s and $1980 \mathrm{~s}$, forty-three students mention that their teachers did discrimination among their students. These discriminations principally appear in their narratives because of their success at their courses, their economic conditions and gender. Apart from them, few narratives reveal that being children of civil servants, neighborhood relations, children of working mothers, speaking Turkish properly and parents' political views become remarkable in discriminating the students.

To begin with, fourteen narratives in three periods reveal that there appeared teachers' discrimination among the students due to their success. As a student of 1970s Yasin Aksu narrates that the achievements of students lead to discrimination partially. He recounts it as "S/he liked the successful students and punished the lazy and naughty ones." Similar discriminations led by the teachers among their students have emerged from the words of other narratives taking place in other studies performed before. The memories of students of Yozgat High School in 1960s render that their teachers discriminated them because of their success at school. Beyhan Arca denotes it as "Our teachers did mostly like the successful students" [15]. Then five students of 1950s, 1970s and 1980s remember that the teachers segregated the children of civil servants and favored them. As a child of a teacher, Özmen Ok who was a primary school student in 1980 s confirms that he was privileged. "I was a child of teacher at that school. Although I had not memorized my poem to recite for the 23th April Ceremony, I was called to read my poem by my teacher. It would not have happened if I hadn't been child of a teacher." Also the recount of Demir Sadık who was a student in Yozgat High School in 1960s reveals that the teacher favored the children of civil servants. "There was that discrimination. You could see that from their treatments. The son of the director of Ziraat Bank' Can a teacher have such an appeal for example? This discrimination was between the children of those who were affluent, with proper outfits and those of the poor. They were scorning us'”[15].

As well as being of children of civil servants, neighborhood relations appear to be source of discrimination in words of two students of 1970s and 1980s. For example, the telling of Kaya Ordulu who got his primary school education in 1980s puts it as, "My father was from Çanakkale as well. My parents had good relations with my two teachers. Thus, they might have favored me." The teachers' relations with the parents of children especially in the villages may result in favoring the children of these families. This could be encountered from the narratives of students of early Republican Turkey. Hülafer Engür's words confirm that as "They liked us much. Our house was close to the school. We were meeting all their needs" [19].

In spite of the fact that we do not across teachers discriminations on account of where they come from we still have an example reflecting that the people coming from city centers discriminated the children coming from the villages. For instance, Nuh Karaca as a primary school student of 1950s objectifies this as "There happened an event like this, when I was chosen as the most successful student of school, a father of a child coming from a leading family in Yozgat had come school and asked my teacher why a child of a villager had been chosen as the best. Both the teacher and school director called me and that child, they asked us questions and I answered all of them and my teacher Mr. Ziya told him that 'no matter who you are, no one can make me do injustice' ",

The narrative of Murat Koçoğlu, a student of 1960s' Yozgat High School, also substantiates the discrimination resulted from coming from villages. He puts it as "There was such a perception among the people both in Akdagmadeni Secondary School and Yozgat High School. In Akdağmadeni, people were discriminated as from the town and the village. In Yozgat, there was discrimination between the ones from Yozgat and the all children from its small towns and villages. You could feel that among the teachers. The friend of you who cheated from your exam paper during the examination was able to get higher grades" [17] In addition to these types of discrimination Le Roux' study that was carried out of Turkey presents significant clues reflecting teachers' narratives about the Bantu Education system in which some teachers mention discrimination. "Bantu education was a well-orchestrated, legalized system aimed at maintaining at all costs white supremacy over black majority. The creation of Bantustans was used to further entrench system." "The creation of homeland system perpetuated apartheid and created discordance amongst blacks" [11].

Despite the fact that forty three students remark their teachers discrimination resulted from certain factors, fifty seven students do not recollect any discrimination and believe that their teachers behaved them equally. For instance, regarding economic conditions they indicate that everybody had similar economic conditions. Rıza Öz as a student of 1970s claims that "I do not think there was such discrimination at that time. We could not feel that. In the village everybody was at the same income level." Also Miraç Karl1 getting his primary school education in 1950s denotes that "No. All of our teachers loved us equally without any segregation. They loved all the students. They were really like that." Ayhan Sağ as student of 1980s puts it as "In our village, none of the teachers let us feel such discrimination. All of the teachers were lecturing equally to everybody. Neither being male or female and rich or poor, I did not feel that."

Briefly, exposing discrimination of teachers from the words of students who are the leading part of education provides not only a rich range of data for the educationalist in order to make use of during the teacher training process but also for the educational policy makers who need to consider the these experiences so that they could reformulate the dominant approaches of teacher training programs. Unless the reasons that lead to emergence of discrimination and the 
educational experiences of children are taken into consideration, it will not be easy to reduce or totally end the teachers' educational practices bringing about discrimination appearing in different forms.

\section{REFERENCES}

[1] Akbaba, Bülent, Kılcan, Bahadır (2012). Sözlü Tarih Çalışmalarına Yönelik Tutum Ölçeğinin Geliştirilmesi: Geçerlik ve Güvenirlik Çalışmalarl, "Development of an Attitude Scale Toward Oral History: Validity and Reliability Study”. Pegem Eğitim ve Öğretim Dergisi .Vol. 2 (1), pp. 110.

[2] Arslan, Yusuf (2013). Sözlü Tarihin Ortaöğretim Öğrencileri Üzerindeki Yansımaları (Tunceli Merkez Örneği), "The Reflections of Oral History On Secondary School Students, An Example of Tunceli City Center"). Türk Tarih Eğitimi Dergisi. Cilt. 2 (1), pp. 1-29.

[3] Büyüköztürk Şener, Çakmak, Ebru Kılıç, Akgün, Özcan Erkan, Karadeniz Şirin \& Demirel, Funda (2013). Bilimsel araştırma yöntemleri, "Scientific Research Methods". Ankara: Pegem Akademi Yayınları.Forum, Vol: 26, No, 1: 57-68.

[4] Connelly, Michael F., Clandinin, Jean D. (1990). Stories of Experience and Narrative Inquiry. Educational Researcher. Vol. 19, No: 5. pp. 2-14.

[5] Ecevit Y1ldız (2003). Toplumsal Cinsiyetle Yoksulluk İliskisi Nasıl Kurulabilir? Bu İliski Nasıl Çalısılabilir?, "How Can a Relation be Established Between Gender and Poverty? How Can This Be Studied?”, C. Ü. Tıp Fakültesi Dergisi, 25 (4): 83-88.

[6] Güçlü, Mustafa (2013). Eğitim Tarihi Araştırmalarında Sözlü Tarih Uygulaması. Türk Eğitim Bilimleri Dergisi, "The Properties and Application of Oral History Method in the Research of History of Education". Vol. 11 (1), pp. 100-113.

[7] Gardner, Philip (2003). Oral history in education: teacher's memory and teacher's history. Vol. 32, No. 2, pp. 175-188.

[8] Gülöksüz, Yiğit., Akgün, Seçil., Kocabaşoğlu, Uygur., Erkal, Funda (1999). "Lisesi Gençlerin Gözüyle Cumhuriyetimiz" Yerel Tarih Yarışması. "Our Republic from the Perspective of High School Students. Local History Race”. İstanbul: Tarih Vakfi.

[9] Haynes, Kathryn (2006). Other Lives in Accounting: Critical Reflections on Oral history Methodology in Action, University of York, [Available online at: http://eprints.whiterose.ac.uk//2582/1/ymswp21 haynes.pdf], Retrieved on June 18, 2013.

[10] Keller Evelyn Fox (2005). Toplumsal Cinsiyet ve Bilim Üzerine Düsünceler, "Reflections on Gender and Science".
(Translated by Ferit Burak Aydar) İstanbul, Metis Yayınları.

[11] Le Roux, Cheryl S (2012). Post-graduate Education Students' Oral History Researc: a Review of Retired Teachers' Experiences and Perspectives of the Former Bantu Education System. Yesterday \& Today. Vol. 8, pp. 87-113.

[12] Marshall, Gordon (1999). Sosyoloji Sözlüğü. "Dictionary of Sociology" (Translated by O. Akınhay and D. Kömürcü). Ankara: Bilim Sanat.

[13] McAdoo, Harriette (1980). Oral History as a Primary Reseource in Educational Research. J. Negro Educ. 49 (4) 414-22.

[14] Öztürk, Serdar (2010). Türkiye'de Sözlü Tarihten İletişim Araştırmaslarında Yararlanma Üzerine Notlar. Milli Folklor. "Some Notes on Using Oral History in Communication Studies in Turkey”. Say1 22 (87), pp. 13-26.

[15] Sağlam, Mehmet (2015). 1960-1970 Period High School Graduates: Our Teachers. Journal of Education and Future. Vol. 8, pp. 103-115.

[16] Sağlam, Mehmet (2015). Primary school students of 1980s of Turkey: remembering their teachers. Educational Research and Reviews. Vol. 10 (6). pp. 761-768.

[17] Sağlam, Mehmet (2015). Mezunlarının Anlatılarıyla 1960-1970 Dönemi Yozgat Lisesi. "Yozgat High School with the Narratives of its Graduates". BAP (Scientific Research Project) Coded 2014 EF/A135. Bozok University.

[18] Sarı, İbrahim (2006). Akademik Tarih ve Tarih Öğreniminde Sözlü Tarihin Yeri ve Önemi, "The Importance of Oral History in Teaching Academic History and History". TSA. Vol. 3, pp. 109-115.

[19] Tan, Mine., Şahin, Özlem., Sever, M. ve Bora, A. (2007). Cumhurite'te Çocuktular, "They Were Children During the Republic”. İstanbul: Boğaziçi Üniversitesi Yayınları.

[20] Thompson, Paul (1988). The Voice of the Past: Oral History. Oxford: Oxford University Press.

[21] URL1, Principles and Best Practices for Oral History Education (4-12), [Available online at: www.oral.history.org/wp-content/uploads/2014/04/2013-141 1_Oral_History_ClassroomGuide_Update_V2_pdf], Retrieved on August 182015.

[22] URL2, Discrimination. [Available online at: http://wikipedia.org/wiki/Discrimination], Retrieved on September 212015.

[23] URL3, What is gender?. FAO Corporate Document Repository. [Available online at: www.fao.org/], Retrieved on September 212015.

[24] Yıldırım, Ali \& Şimşek, Hasan (2005). Sosyal Bilimlerde Nitel Araştırma Yöntemleri, "Qualitative Research Methods in social Sciences". Ankara: Seçkin. 